\title{
Agro-economic models: a review and directions for research
}

\author{
M. Nehrey ${ }^{1}$, A. Kaminskyi ${ }^{2}$, M. Komar ${ }^{3}$ \\ ${ }^{1}$ Department of Economic Cybernetics, National University of Life and Environmental Sciences of Ukraine \\ ${ }^{2}$ Department of Economic Cybernetics, Taras Shevchenko National University of Kyiv \\ ${ }^{3}$ Department of Economic Cybernetics, Ivan Franko National University of Lviv
}

Article Info

Received Mar 7, 2019

\section{Keyword:}

Agricultural market

Agricultural policy

Computable General

Equilibrium model

Economic modelling

Partial Equilibrium model

\begin{abstract}
The article is devoted to reviewing of main 8 models, which are used to analyze the agriculture sector, medium, and long-term forecasts, as well as policy making. The review is based on comparative analysis of models conducted by the authors according to a number of criteria. On its basis, formed the distinctive features of modeling, which are realized in these models. The first distinctive feature is the problem of choosing the level of aggregation in models. This feature generates the direction of research about the effectiveness of the application of one or another aggregation level in modeling. The second distinctive feature of modeling is structurization models into two types: partial equilibrium and computable general equilibrium models. The method of choosing the type of model is one of the actual problems. The third distinctive feature is dominance of deterministic approaches in the construction of models. The use of stochastic analysis in models, in the opinion of the authors, does not yet have a system analysis. Based on the carried out analysis, the authors tried to form directions for the development of the agriculture sector modeling.
\end{abstract}

\section{Corresponding Author:}

Maryna Nehrey,

Department of Economic Cybernetics,

National University of Life and Environmental Sciences of Ukraine,

Kyiv, Ukraine.

Email: marina.nehrey@gmail.com

\section{Introduction}

Modeling of scenarios for global agriculture has become more significant for agricultural policy design. The situation on a world agriculture market such as agricultural and food prices rising and forecasts for real commodity prices cause concerns about the capacity of the agriculture to provide increasing demand. Agroeconomic models is the tools, wich can help to analyze possible developments in the future and alternative strategies to influence these developments.

Agriculture sector models allow a better understanding of the diversity of interrelations and factors, substantiate causal relationships, study the long-term effects of making decisions, systematically examine trade processes both at the regional and international levels, to conduct scenario calculations and to assess their consequences, etc.

\section{Materials and methods}

The methodology of analyzing the agriculture sector involves the use of a system of models and their program implementation, which provide multivariate analytical and predictive calculations. There are two types of models for agro-economic system: partial equilibrium and computable general equilibrium models. 
Partial equilibrium models (PE) depict the behavioral interactions of the agriculture sector, whilst modeling results in other sectors as exogenous and hence unaffected by development in the sector(s) represented. PE models used to model the impact of development on the agriculture sector most instantly related to a problem (production and use of primary agricultural commodities, including their use as intermediate inputs to agriculture itself).

The feedback of these influences is not modeled in PE models. However, models may include relationships with individual sectors (oil, dairy products, feed concentrate, etc.) with close links to primary agriculture or the economy as a whole (eg land competition based on supply curves). The overall structure of PE models covers technical, accounting and behavioral equations based on statistical data, technical knowledge of the agriculture sector and forecasts of exogenous factors.

PE models are used for a system modeling of interactions in agricultural production of different products with special attention on demand, supply, and prices of different products. PE models consider only the agricultural sector without taking into account the relationships with the rest of the economy.

A computable general equilibrium (CGE) models are used for modeling of the behavior of all participants of the world economy such as producers, consumers, importers, exporters, investors, taxpayers, and government. In CGE models depict the behavioral interactions of the agriculture sector and all economies for one country, a region or even all countries worldwide. CGE models consider inter-industry relations and the influence of international trade on the economy as a whole, as a separate sector. Therefore CGE models are appropriate for modeling of the relationship between agriculture and other sectors in the economy.

In this paper, we compare partial equilibrium models AGLINK-COSIMO, AGMEMOD, CAPRI, ESIM, and FAPRI, and computable general equilibrium models CGERegEU+, GTAP, and MAGNET.

\section{Results and discussion}

\subsection{Overview of the models}

AGLINK-COSIMO. It combines two models: AGLINK (OECD) and COSIMO (FAO).The model work for members of both organizations. AGLINK-COSIMO covers 52 countries and regions, and all main areas of agricultural productions.

AGLINK-COSIMO modeling markets factors for the main agricultural products, which are producing, consuming and trading in each of the regions it contains.

The AGLINK country modules are modeling market circumstance and national agriculture policies. The COSIMO modules gives forecasts, which based on an FAO market analysts expertise and model-driven calculations. Therefore modules are integrated to the full AGLINK-COSIMO model.

For each country, an autonomous model is being built, which considers the world market as exogenous variables.

AGLINK-COSIMO has been used in the analysis of the effects of economic growth scenarios on agricultural [1], analysis of commodity balances and trade [2], for agriculture policy modeling [3].

AGMEMOD. AGricultural MEmber states MODelling used for multimarket modeling with taking to account important factors of the agricultural sector.

The model includes EU-28 members (except Malta) and some nonEU countries. The rest of the world is interpreted as exogenous factors such as world prices, tariffs, and subsidies.

AGMEMOD modeling agriculture of EU as a whole. The model was built at the country level and calibrated for those parameters which could not be estimated. AGMEMOD simulate agriculture sectors feedback to price volatility, government policy, the macroeconomic situation, and other exogenous factors.

The model uses a template for each country. Thus, it allows to provide analytical consistency for all countries and simulate the details. On the countries level, the model reflects agriculture policies which are modeled based on historical time series data.

AGMEMOD has been used in the analysis of agriculture policies [4], impact of some countries on the world market prices [5].

CAPRI. Common Agricultural Policy Regionalised Impact model is modeling the agricultural sector in the EU. The model combines supply and market modules. Supply module includes about 2000 farm regional 
models more than 50 crop and animal products for each of the regions and including more than 50 exogenous and endogenous factors. The significance is on crops and livestock.

CAPRI is used by European researches and is often revised. The CAPRI combines a high-level detailing of European agriculture, wild coverage of economic factors, full European and world coverage and the effective network. Therefore CAPRI is used in many different types of research and applications. However, these advantages cause the high price of maintenance costs.

CAPRI has been used in the analysis of free trade agreement [6], land use effects [7], climate change impacts [8], in simulation of reform policies [9].

ESIM. European Simulation Model is modeling supply and demand for the agricultural sector, in particular of cross-commodity linkages. It consists of such policy instruments as quotas, subsidies, intervention and threshold prices, direct payments for keeping land in agricultural use, etc. Policies are modeled only for EU and accession candidates. All behavioral functions in ESIM are isoelastic.

ESIM has two versions: comparative static and recursive dynamic. First version use for medium- and longterm projection of equilibrium states. The second version includes a lagged supply response exists. ESIM takes into account supply and demand shifters. Simulations are typically made for a period of up to 15 years beyond the base period.

ESIM is modeling technological progress in agriculture, agricultural policy and trade EU policy.

ESIM has been used in the analysis of the effects of yield instability on agricultural prices [10], [11], [12], in the analysis of climate change scenarios [13]. Furthermore, ESIM has been used for modeling functioning of factor markets for agriculture [14], [15].

FAPRI. The Food and Agricultural Policy Research Institute model [16] has developed as a system of stochastic modeling with the significance of the agricultural sector in the United States. FAPRI models cover world markets of dairy products, grains, livestock, oilseeds, sugar, and crop insurance. It covers 61 countries. For each of these markets simulated separate models.

FAPRI model combines deterministic and stochastic approaches. The deterministic model analyzes one projection system on 10 years, which based on average conditions of agricultural markets. The stochastic model simulated 500 alternative projections, which based on different conditions of agricultural markets and other exogenous factors. For stochastic modeling, FAPRI uses a Monte Carlo model.

CGERegEU+ model is a system of CGE countries models with emphasis on rural development. It consists of 270 NUTS 2 regions for all EU countries. CGERegEU+ model uses Leontief and Armington assumption. CGE countries models optimize firms profits, consumers utility, the production function, and expenditure.

The model provides modeling of capital, labour, and land. The labour market plays a fundamental role in the CGERegEU+ and allows simulation with fixed wages, the wage curve, or fully free. The rest of the world is modeled as a small open economy model using import supply and export demand functions.

CGERegEU+ can be practiced as a separate model or combined with the CAPRI model. In this case, CAPRI simulates return of capital, labour and land use in agriculture pass to CGERegEU+. CGERegEU+ transfer nonagricultural prices, capital and labour use of agriculture sector to CAPRI.

GTAP. Global Trade Analysis Project model based on perfect competition and use constant returns to scale. GTAP use multilevel constant elasticity of substitution (CES). It uses for an explanation of factors substitution, in particular, natural resources, capital, labor, and land. Modeling production factors such as energy, animal feed components, also based on this approach. GTAP distinguishes one household for one region. It simulates consumptions incomes, expenditures, savings. The model analyzes government expenditures, regional resources, capital, labor, and land. Thus, for capital and labor markets two possibilities are distinguished. Wage differentials between agriculture and nonagriculture can be sustained in many countries through limited off-farm labor migration.

GTAP has been used in the analysis of the relationship between commodity price volatility and energy prices [17], [18], spillover and welfare effects [19], the impacts of trade policy responses to rising world food prices [20] and graphical exposition of global trade [6]. 


\section{MAGNET}

The Modular Applied General Equilibrium Tool has a modular design that makes adapting the structure of the model to the needs of the researchers. MAGNET allows you to select from a list of non-stand-alone modules that are most likely to be downloaded for research. The original attention is paid to the development of regional agricultural enterprises.

The model shows the importance of the agrarian sector and sales patterns in order to reassure the interests of replacing emissions, changes in the use of land and the relative differentiation of the paid payment between the agricultural and non-agricultural enterprises and the capital stock. At the same time, the template allows for changes in the structure of the elasticity of an inquiry on agricultural trade in goods with a long time due to contingencies of exogenous changes.

MAGNET has been used in the analysis of the economy-wide effects of policy measures [22] [23], climate change impacts [8], and research of functioning of factor markets for agriculture [14].

\subsection{Comparison of the models}

Once the main model baselines have been described, the main similarities and differences will be shortly discussed. The review will then focus on the main modelling systems used for agriculture policy design. Table 1 provides an analysis of the main properties of models.

Table 1. Comparison of the models

\begin{tabular}{|c|c|c|c|c|c|}
\hline & Model type & $\begin{array}{l}\text { Equilibrium } \\
\text { type }\end{array}$ & $\begin{array}{l}\text { Baseline } \\
\text { definition }\end{array}$ & Exogenous drivers & World disaggregation \\
\hline $\begin{array}{l}\text { AGLINK- } \\
\text { COSIMO }\end{array}$ & $\begin{array}{l}\text { Recursive } \\
\text { dynamic }\end{array}$ & PE & $\begin{array}{l}\text { Own baseline } \\
\text { projections }\end{array}$ & $\begin{array}{l}\text { Population, macro } \\
\text { factors, technical } \\
\text { innovation }\end{array}$ & $\begin{array}{l}58 \text { countries regions, } \\
\text { including the main } \\
\text { trading blocks }\end{array}$ \\
\hline AGMEMOD & $\begin{array}{l}\text { Recursive } \\
\text { dynamic }\end{array}$ & $\mathrm{PE}$ & $\begin{array}{l}\text { Own baseline } \\
\text { projections }\end{array}$ & $\begin{array}{l}\text { Population, macro } \\
\text { factors, technical } \\
\text { innovation }\end{array}$ & $\begin{array}{l}\text { EU (except Malta), } \\
\text { Croatia, the Former } \\
\text { Yugoslav Republic of } \\
\text { Macedonia and Turkey }\end{array}$ \\
\hline CAPRI & $\begin{array}{l}\text { Comparative } \\
\text { static }\end{array}$ & $\mathrm{PE}$ & $\begin{array}{l}\text { Calibration to } \\
\text { DG-AGRI } \\
\text { baseline }\end{array}$ & $\begin{array}{l}\text { Population, macro } \\
\text { factors, technical } \\
\text { innovation }\end{array}$ & $\begin{array}{lr}\text { EU28, Norway, } \\
\text { Western } \\
\text { Turkey }\end{array}$ \\
\hline ESIM & $\begin{array}{l}\text { Comparative } \\
\text { static }\end{array}$ & $\mathrm{PE}$ & $\begin{array}{l}\text { Calibration to } \\
\text { DG-AGRI } \\
\text { baseline }\end{array}$ & $\begin{array}{l}\text { Population, macro } \\
\text { factors, technical } \\
\text { innovation }\end{array}$ & $\begin{array}{l}\text { Only EU, US, Turkey } \\
\text { and RoW }\end{array}$ \\
\hline FAPRI & $\begin{array}{l}\text { Recursive } \\
\text { dynamic }\end{array}$ & $\mathrm{PE}$ & $\begin{array}{l}\text { Own baseline } \\
\text { projections }\end{array}$ & $\begin{array}{l}\text { Population, macro } \\
\text { factors, technical } \\
\text { innovation }\end{array}$ & $\begin{array}{l}26 \text { countries regions, } \\
\text { including the main } \\
\text { trading blocks }\end{array}$ \\
\hline CGERegEU+ & $\begin{array}{l}\text { Comparative } \\
\text { static }\end{array}$ & CGE & $\begin{array}{l}\text { Calibration to } \\
\text { DG-AGRI } \\
\text { baseline }\end{array}$ & $\begin{array}{l}\text { Population, macro } \\
\text { factors, technical } \\
\text { innovation, land, } \\
\text { labor, capital }\end{array}$ & EU \\
\hline GTAP & $\begin{array}{l}\text { Comparative } \\
\text { static }\end{array}$ & CGE & $\begin{array}{l}\text { Calibration to } \\
\text { DG-AGRI } \\
\text { baseline }\end{array}$ & $\begin{array}{l}\text { Population, macro } \\
\text { factors, technical } \\
\text { innovation, land, } \\
\text { labor, capital, } \\
\text { natural resources, } \\
\text { energy }\end{array}$ & $\begin{array}{l}113 \text { countries and } \\
\text { regions }\end{array}$ \\
\hline MAGNET & $\begin{array}{l}\text { Comparative } \\
\text { static }\end{array}$ & CGE & $\begin{array}{l}\text { Own baseline } \\
\text { projections }\end{array}$ & $\begin{array}{l}\text { Population, macro } \\
\text { factors, technical } \\
\text { innovation, land, } \\
\text { labor, capital, } \\
\text { natural resources, } \\
\text { energy }\end{array}$ & 140 countries/regions \\
\hline
\end{tabular}


In this paper, we investigated different PE and CGE approaches to model agriculture sector. Tables 2 and 3 provides a condensed summary of some of the major studies using PE and CGE models that are reported in this paper.

Table 2. Condensed summary of some key PE analysis

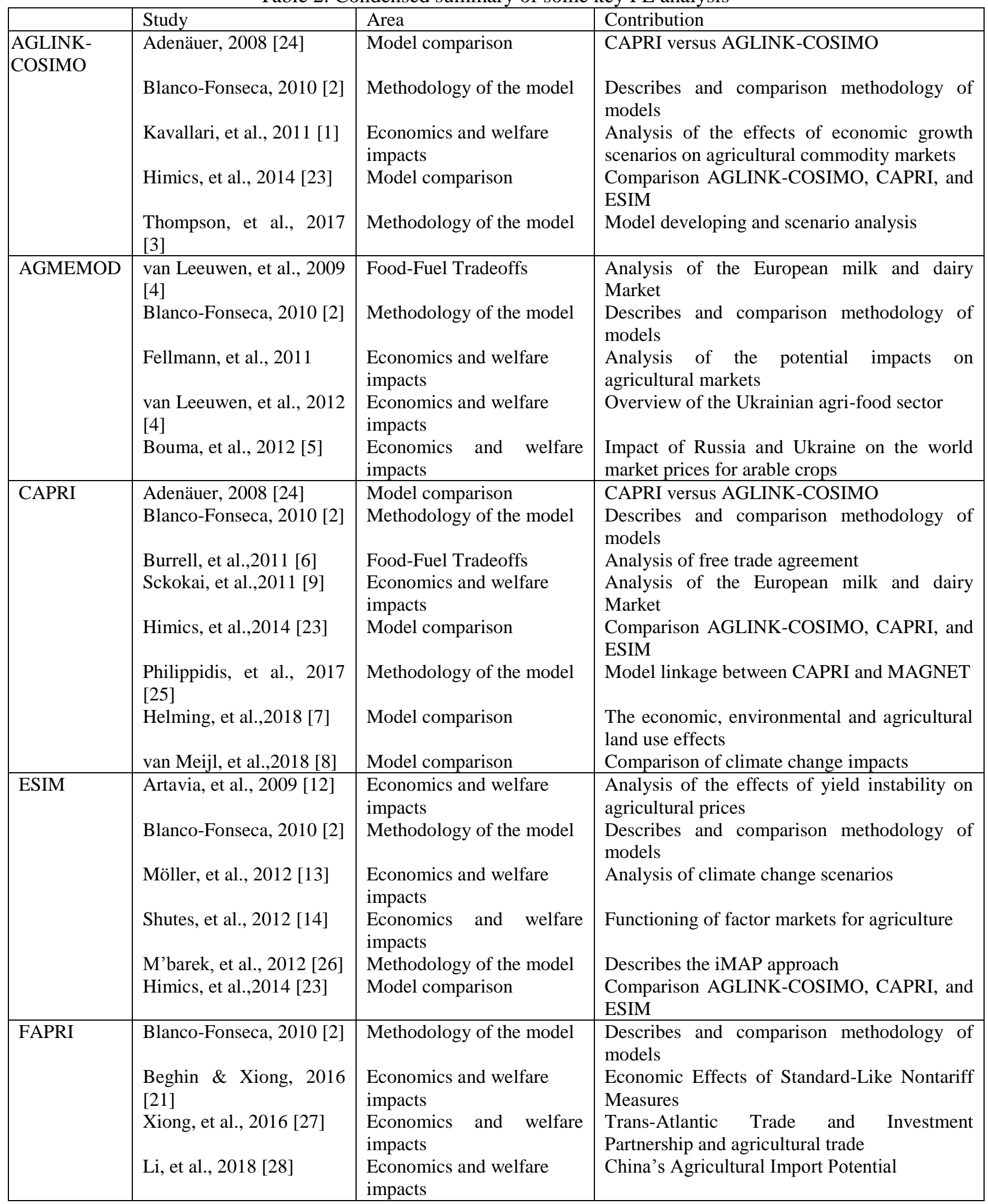


Table 3. Condensed summary of some key CGE analysis

\begin{tabular}{|c|c|c|c|}
\hline & Study & Area & Contribution \\
\hline CGERegEU+ & $\begin{array}{l}\text { Törmä, } 2010 \text { [29] } \\
\text { Wania, et al., } 2013 \text { [30] }\end{array}$ & $\begin{array}{l}\text { Methodology of the model } \\
\text { Economics and welfare } \\
\text { impacts }\end{array}$ & $\begin{array}{l}\text { Describes methodology of the model } \\
\text { Common Agricultural Policy Regional Impact }\end{array}$ \\
\hline GTAP & $\begin{array}{l}\text { Britz and Hertel, } 2011 \\
\text { [31] } \\
\text { Hertel and Beckman, } \\
2011 \text { [17] } \\
\text { Satyakti, et al., } 2012 \\
\text { [19] } \\
\text { Rutten, et al., } 2013 \\
\text { [20] } \\
\text { Sajedinia, et al., } 2014 \\
\text { [32] }\end{array}$ & $\begin{array}{l}\text { Food-Fuel Tradeoffs } \\
\text { Food-Fuel Tradeoffs } \\
\text { Economics and welfare } \\
\text { impacts } \\
\text { Food-Fuel Tradeoffs } \\
\text { Model comparison }\end{array}$ & $\begin{array}{l}\text { Linking GTAP with CAPRI } \\
\text { Relationship between commodity price } \\
\text { volatility and energy prices } \\
\text { Spillover and welfare effects } \\
\text { The impacts of trade policy responses to } \\
\text { rising world food prices } \\
\text { Comparison of CGE models in case of } \\
\text { biofuels policies }\end{array}$ \\
\hline MAGNET & $\begin{array}{l}\text { Woltjer, et al., } 2014 \\
\text { [33] } \\
\text { Banse, et al., 2013 [34] } \\
\text { Lotze Campen, et al., } \\
2014 \text { [35] } \\
\text { Shutes, et al., } 2012 \\
\text { [14] } \\
\text { Philippidis, et al., } 2017 \\
\text { [25] } \\
\text { van Meijl, et al.,2018 } \\
\text { [8] } \\
\text { Helming, et al.,2018 } \\
\text { [7] }\end{array}$ & $\begin{array}{l}\text { Methodology of the model } \\
\text { Economics and welfare } \\
\text { impacts } \\
\text { Economics and welfare } \\
\text { impacts } \\
\text { Economics and welfare } \\
\text { impacts } \\
\text { Methodology of the model } \\
\text { Model comparison } \\
\text { Model comparison }\end{array}$ & $\begin{array}{l}\text { Describes methodology of the model } \\
\text { Analysis of the economy-wide effects of } \\
\text { policy measures } \\
\text { Comparing results from AIM, MAGNET and } \\
\text { PE Models } \\
\text { Functioning of factor markets for agriculture } \\
\text { Model linkage between CAPRI and } \\
\text { MAGNET } \\
\text { Comparison of climate change impacts } \\
\text { Model linkage between CAPRI and } \\
\text { MAGNET }\end{array}$ \\
\hline
\end{tabular}

\subsection{Implication of the stochastic component into agro-economic modeling}

The considered in our review models include quite a lot of parameters that have stochastic nature. These include, in particular, corp capacity and product prices. The stochastic nature of corp capacity is well illustrated by the example of wheat production in the two largest EU countries - Germany and France. Data analysis (by using www.factfish.com/statistic-country) over a period of 20 years (from 1998 to 2017) indicates range 8,5 bln.tons for Germany and 13,2 bln.tons for France (standard deviations are 2,39 bln and 3,31 bln correspondingly). Graphs are presented at Fig.1. Illustration of wheat price stochasticity is done at Fig.2. It is possible to observe analogous stochastic properties in most prices of agricultural products if not all (rice, sugar, coffee, soybean and so on) (as ex. [36], [37],[38]). 


\section{Wheat production in 1998-2017 (tons): Germany (lower graph) and France (upper graph)}

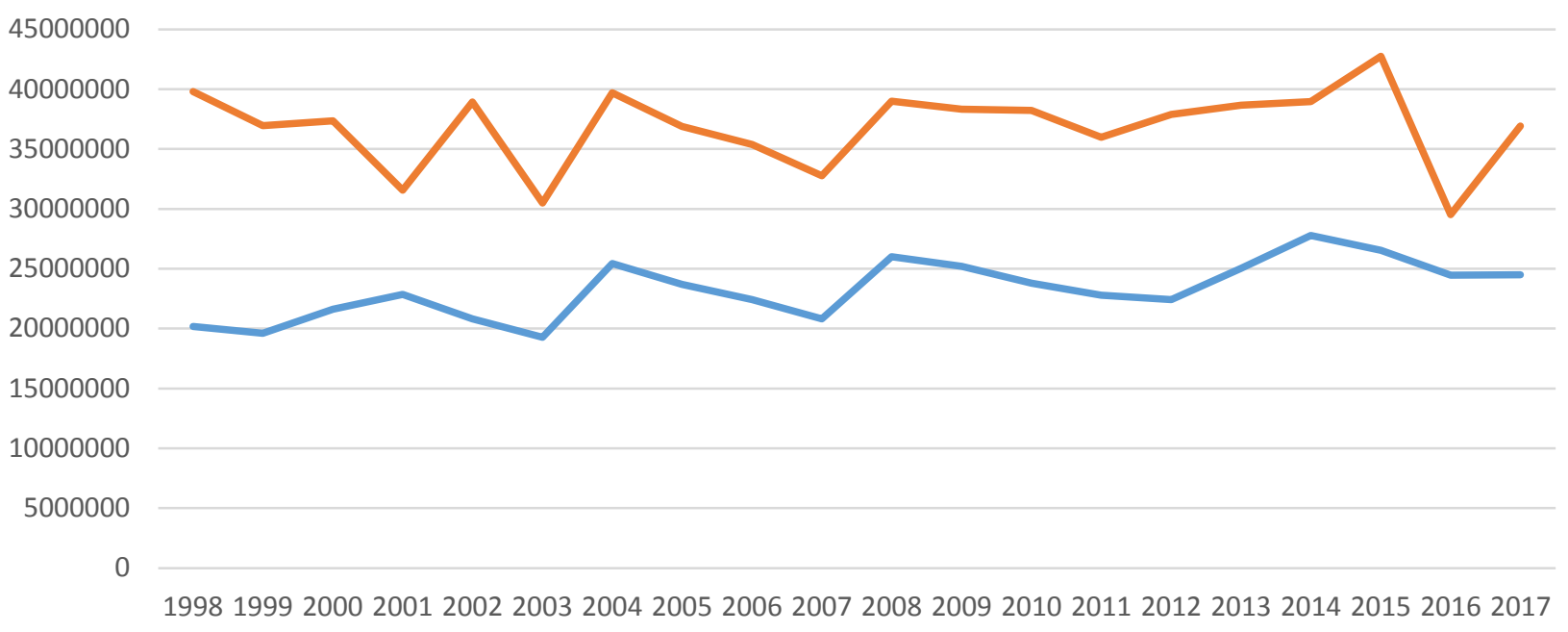

Figure 1. Volatile of wheat crop capacity in Germany and France

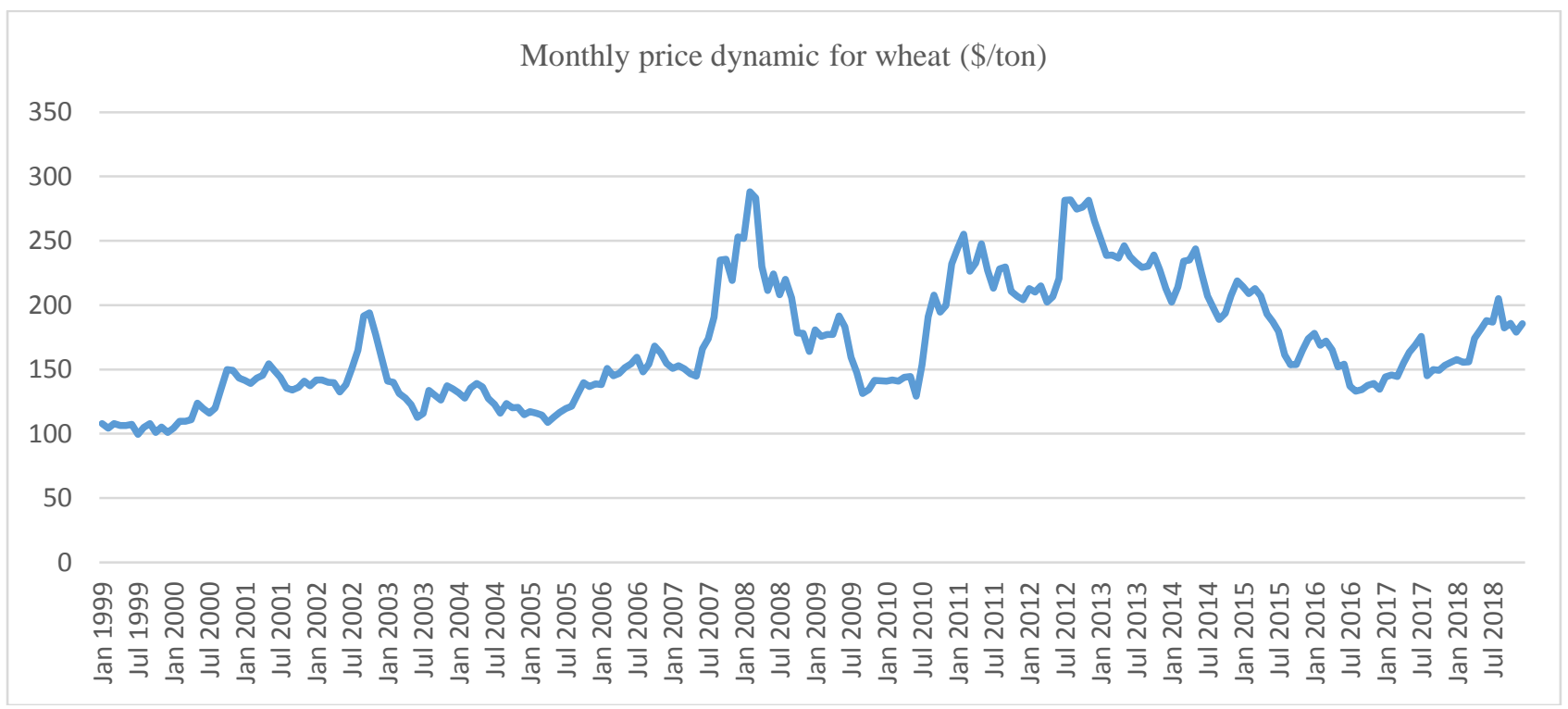

Figure 2. Volatile of wheat price

The stochastic component also presents in the institutional context. Export and import values of agricultural products may essentially vary as a consequence of policy changes, tariffs changes etc. Ukrainian example can be used for illustration. After the revolutionary events in 2014, a declaration of association with the European Union was signed. Export of cereals from Ukraine to EU have increased since 2014: it is 58,12 bln.tons in 2017/2018 in comparison 29,30 bln.tons in 2013/2014 (increasing two times).

The stochastic nature of the model`s constituent elements generates risks associated with the adequacy of the modeling results and forecasting. Therefore, in our opinion, the implementation of stochastic analysis can be one of the important directions in the further development of this modeling and its application. Based on such analysis risk of deviations from baseline results can be carried out.

It should be noted that stochasticity is considered in most of the models which we examined in this review. Our review can identify three approaches for analyzing the stochastic component. First approach is a scenario approach (example, AGLINK-COSIMO, FAPRI and other). Such approach is useful for elaboration design of decision making in different scenarios. The second approach consists in applying Monte Carlo simulation. This method is applied in models FAPRI, ESIM and some others. It is interesting that application ESIM supposes to estimate the variance of results which modeled by Monte Carlo simulations. This is one of a 
number of approaches for the estimation validity of modeling. The third approach is based on sensitivity analysis which can be applied on the post-modeled stage (example CAPRI).

Based on our review and analysis we think, that the extension of the systematic application of risk assessment is the potential effective direction. Now models involve only a couple of approaches from their wide spectrum. We think that it will be fruitful to consider the application of the ISO 31000 "Risk management Principles and guidelines" (ISO 31000) for constructing methodology of the stochastic component into the agro-economics models. In such a way possible to apply first of all risk assessment activity: risk identification, risk analysis, and risk evaluation. Risk identification should define main risks involving into the model considering (volatility of crop capacity, price changing etc.). Risk analysis includes a number of methods which supplement above mentioned. Especially, statistical, analogical and expert methods of risk analysis may be applied before "model launching". Also, it is important to construct some risk measures which assess possible deviations from the results of modeling.

\section{Conclusion}

Modeling of agro-economics is the dynamically developing sphere, which has a lot of facets. In our review, we presented a comparative analysis of 8 models and tried to identify possible directions of conceptual development on its basis.

The first distinctive feature of this modeling is the problem of choosing the level of aggregation. Aggregation can include both the world level (for example, models MAGNET or GTAP), and regional (many models are focused, in particular, on the EU agricultural sector). At the same time, we see the openness of the question about the effectiveness of choosing/applying models of various levels. It is especially interesting how effective the application of the «ROW» approach in regional models.

The second distinctive feature of modeling is structurization models into 2 types - partial equilibrium and computable general equilibrium models. Each type of model has certain strengths and weaknesses. Typically, PE models measure outputs and inputs in physical units (metric tons, hectares, heads etc.), and not, as in CGEs, as dimensionless quantity indices. This not only allows for the inclusion of technical links, but also policy tools such as quotas, tariffs can be modeled so that they are in line with legal and regulatory constraints. This facilitates both the connection with market experts and linkages to biophysical tools, as well as the calculation of environmental indicators. Although the share of agriculture in the economy is shrinking, there is a growing need for modeling tools that can analyze trends in the world market, take into account recent political developments and EU enlargements, and provide a sound basis for policy design. The PE models detail the product characteristics and relationship between them. Their feature is the flexibility in modeling agrarian policy and its tools. CGE models are often modeled in a less aggregate manner, mainly due to the high aggregation of products and less flexibility in the description of agricultural policies. But CGE models are well suited for representing a variety of relationship between agriculture and other sectors of the economy. To combine the advantages of both model types, the PE model and the CGE model, it is a promising analytical approach to integrate CGE and PE models to analyze agricultural policy scenarios. In case of using a subset of all variables being endogenous in both of the models, the integration of simulation models should be an iterative process which uses two models at different aggregation stages.

The third distinctive feature of modeling is a certain dominance of deterministic approaches in the construction of models. The certain baseline is typical results of such approach. At the same time, some methods are used to display the stochastic nature of the constituent elements of models. There are scenario method, Monte Carlo method and the sensitivity method most often used. In our opinion, the systematic application of the approaches of stochastic analysis and risk management is one of the promising areas of modeling agro-economics.

\section{Acknowledgements}

Authors are thankful to the organizers and participants of the ICCMIT'19 held at Vienna, Austria during 2628 March 2019, where the initial version of this paper was presented. Reviewer's comments are gratefully acknowledged. Useful disclaimers apply.

\section{REFERENCES}

[1] A. Kavallari, T. Fellmann and S. Gay, "Shocks in economic growth= shocking effects for food security?", Food Security, vol. 6, no. 4, pp. 567-583, 2014. Available: 10.1007/s12571-014-0368-y.. 
[2] M. Blanco-Fonseca, "Literature review of methodologies to generate baselines for agriculture and land use.", Sevilla Abrufbar, 2010.

[3] W. Thompson, J. Dewbre, S. Pieralli, K. Schroeder, I. Pérez Domínguez and P. Westhoff, "Long-term crop productivity response and its interaction with cereal markets and energy prices", Food Policy, vol. 84, pp. 1-9, 2019. Available: 10.1016/j.foodpol.2018.12.001.

[4] M. Leeuwen et al., The agri-food sector in Ukraine. Luxembourg: Publications Office, 2012.

[5] M. Banse et al. "Impact of Russia and Ukraine on the international price formation and the EU marketsA Model based analysis." No. 706-2016-48356. 2012.

[6] A. Burrell, E. Ferrari and A. González Mellado, Potential EU-Mercosur free trade agreement. Luxembourg: Publications Office, 2011.

[7] J. Helming and A. Tabeau, "The economic, environmental and agricultural land use effects in the European Union of agricultural labour subsidies under the Common Agricultural Policy", Regional Environmental Change, vol. 18, no. 3, pp. 763-773, 2017. Available: 10.1007/s10113-016-1095-z.

[8] H. van Meijl et al., "Comparing impacts of climate change and mitigation on global agriculture by 2050", Environmental Research Letters, vol. 13, no. 6, p. 064021, 2018. Available: 10.1088/17489326/aabdc4 [Accessed 26 June 2019]..

[9] M. Kempen, P. Witzke, I. Pérez Domínguez, T. Jansson and P. Sckokai, "Economic and environmental impacts of milk quota reform in Europe", Journal of Policy Modeling, vol. 33, no. 1, pp. 29-52, 2011. Available: 10.1016/j.jpolmod.2010.10.007.

[10] S. Adebayo, "A Review of Decision Support System Using Mobile Applications in the Provision of Day to Day Information about Farm Status for Improved Crop Yield", Periodicals of Engineering and Natural Sciences, vol. 6, no. 2, 2019.

[11] V. Babenko, "Formation of economic-mathematical model for process dynamics of innovative technologies management at agroindustrial enterprises", Actual Problems of Economics, vol. 139, no. 1, pp. 182-186, 2019.

[12] M. Artavia, H. Grethe and G. Zimmermann, "Stochastic market modeling with Gaussian Quadratures: Do rotations of Stroud's octahedron matter?", Economic Modelling, vol. 45, pp. 155-168, 2015. Available: 10.1016/j.econmod.2014.10.017.

[13] T. Möller, H. Grethe, K. Waha, \& C. Müller. "Modeling Climate Change Impacts on European Agriculture: Does the Choice of Climate Models matter". In XIIIth EAAE Congress" Change and Uncertainty: Challenges for Agriculture, Food and Natural Resources", 2011

[14] L. Shutes, M. Banse and A. Rothe, Factor markets in applied equilibrium models. Brussels, Belgium: Centre for European Policy Studies, 2012.

[15] Shorikov, and V. Babenko. "Optimization of assured result in dynamical model of management of innovation process in the enterprise of agricultural production complex", Economy of Region, is. 1, pp. 196-202.

[16] FAPRI-MU, 2011. [Online]. Available: https://www.fapri.missouri.edu/wocpresentations2011/.

[17] T. Hertel, J.Beckman. Commodity price volatility in the biofuel era: an examination of the linkage between energy and agricultural markets. In The Intended and Unintended Effects of US Agricultural and Biotechnology Policies University of Chicago Press: pp. 189-221.

[18] L. Zomchak and M. Nehrey, Econometric modeling of functioning and development of the agricultural sector of Ukraine. Kyiv: Comprint, 2018. [in Ukrainian].

[19] Y. Satyakti, B. Havrland and V. Pobedischi, "IMPACT OF EU BIOFUEL DIRECTIVES POLICIES ON DEVELOPING ECONOMIES", in 11th International Scientific Conference: Engineering for rural development, Latvia University of Agriculture, 2012.

[20] M. Rutten, L. Shutes, G. Meijerink. "Sit down at the ball game: How trade barriers make the world less food secure", Food Policy, 38, pp. 1-10. 
[21] J. Beghin, B. Xiong. Economic Effects of Standard-Like Nontariff Measures: Analytical and Methodological Dimensions. CARD Working Papers, 2016.

[22] M. Nehrey, I. Chabanenko."Partial equilibrium models as a tool for research of agriculture sector", Black Sea Economic Studies, vol.36, pp.326-331. [in Ukrainian].

[23] M. Himics, M. Artavia, S. Hélaine S. (2014) Calibrating the CAPRI and ESIM models to the mid-term commodity market outlook of the European Commission. Joint Research Centre - Institute for Prospective Technological Studies, 2014.

[24] M. Adenäuer, "CAPRI versus AGLINK-COSIMO. Two partial equilibrium models-Two baseline approaches", in 12th Congress of the European Association of Agricultural Economists (EAAE), pp. 2629.

[25] G. Philippidis, J. Helming, A. Tabeau. Model linkage between CAPRI and MAGNET: An exploratory assessment. JRC Technical Reports. Luxembourg: Publications Office of the European Union, 2017.

[26] R. M'barek, W. Britz, A. Burell, J. Delincé, J. An integrated modeling platform for agro-economic commodity and policy analysis (iMAP)-a successful European experiment. JRC Scientific and Policy Report, European Commission, Seville, Spain, 2012.

[27] B. Xiong and J. C. Beghin, "TTIP and agricultural trade: The case of tariff elimination and pesticide policy cooperation," Agribusiness, vol. 34, no. 3, pp. 495-508, 2018.

[28] M. Li, W. Zhang, D. Hayes, "China's Agricultural Import Potential (No. 18-pb23)," Food and Agricultural Policy Research Institute (FAPRI) at Iowa State University 2018.

[29] H. Törmä, K. Zawalinska. Final documentation of the CGERegEU+ model. FP7 CAPRI-RD project, Deliverable 3.2. 3, 2011.

[30] A. Wania, F. Ramos, J. Terres. Report on methodology to update land use map based on CAPRI/CGERegEU+ baseline and code implementation, 2013.

[31] W. Britz and T. W. Hertel, "Impacts of EU biofuels directives on global markets and EU environmental quality: An integrated PE, global CGE analysis," Agriculture, Ecosystems \& Environment, vol. 142, no. 1-2, pp. 102-109, 2011.

[32] E. Sajedinia, W. Tyner. Use of General Equilibrium Models in Evaluating Biofuels Policies, in 20th GTAP Annual Conference on Global Economic Analysis, West Lafayette, IN, 2017.

[33] G. Woltjer, M. Kuiper, A. Kavallari, H. van Meijl, J. Powell, M. Rutten, A. Tabeau. The MAGNET model: Module description (No. 14-57). LEI Wageningen UR, 2014.

[34] M. Banse, H. Grethe. "Top down, and a little bottom up: modelling EU agricultural policy liberalization with LEITAP and ESIM," in Contributed paper at the 11th Annual Conference on Global Economic Analysis, Helsinki, Finland, 2008.

[35] H. Lotze-Campen, M. V. Lampe, P. Kyle, S. Fujimori, P. Havlik, H. V. Meijl, T. Hasegawa, A. Popp, C. Schmitz, A. Tabeau, H. Valin, D. Willenbockel, and M. Wise, "Impacts of increased bioenergy demand on global food markets: an AgMIP economic model intercomparison," Agricultural Economics, vol. 45, no. 1, pp. 103-116, 2013.

[36] A. Kaminskyi. "Risk management: recent developments and issues", Scientific Papers NaUKMA. Economic Sciences. V 2, N. 1, pp. 52-59, 2017. [in Ukrainian].

[37] T. Banerjee, M. Mishra, N. Debnath, and P. Choudhury, "Implementing E-Commerce model for Agricultural Produce: A Research Roadmap," Periodicals of Engineering and Natural Sciences, vol. 7, no. $1,2019$.

[38] J.L. Harwood, Managing risk in farming: concepts, research, and analysis. Washington, DC: U.S. Dept. of Agriculture, ERS, 1999. 